Historia i Polityka

Półrocznik poświęcony myśli politycznej i stosunkom międzynarodowym

$\mathrm{Nr} 10(17) / 2013$ 137-141

DOI: http://dx.doi.org/10.12775/HiP.2013.017

Arkadiusz Lewandowski (Uniwersytet Mikołaja Kopernika w Toruniu)

\title{
Joanna Sanecka Tyczyńska \\ Państwo obywatelskie i wspólnota polityczna Studium o myśli politycznej Prawa i Sprawiedliwości Wydawnictwo Uniwersytetu Marii Curie-Skłodowskiej Lublin 2011, ss. 302
}

W spółczesna polityka w dobie dominacji mediów i marketingu narracyjnego sprawia, że programy polityczne partii politycznych nie rozgrzewają już umysłów wyborców. Ta swoista deideologizacja polityki, uczynienie z niej w zasadzie technologii zarządzania ma swoje konsekwencje w tym, że programy polityczne, a ogólniej mówiąc myśl polityczna przestaje mieć znaczenie. Partie i środowiska polityczne, które nadal tworzą kilkuset stronicowe opracowania programowe uznawane są za archaiczne, nie rozumiejące współczesnej rywalizacji politycznej. Jednym z takich ugrupowań jest Prawo i Sprawiedliwość, które swego czasu z faktu posiadania, bądź braku programu politycznego próbowało uczynić oś rywalizacji politycznej.

Mimo zaznaczonego powyżej swoistego upadku programów politycznych polska politologia nadal jednak poddaje badaniom ten obszar rzeczywistości politycznej ${ }^{1}$. Przy-

\footnotetext{
1 Zob. Myśl polityczna w Polsce po 1989 roku,
}

kładem tych starań jest chociażby recenzowana tu praca Joanny Saneckieja-Tyczyńskiej, która w swojej książce przeprowadziła studia nad myślą polityczną partii Jarosława Kaczyńskiego. Autorka, politolog z Uniwersytetu Marii Curie-Skłodowskiej, w swoich artykułach już niejednokrotnie przedstawiała wyniki swoich badań na temat współczesnej myśli politycznej, tym razem jednak proponuje czytelnikowi opracowanie myśli politycznej jednego środowiska politycznego, jakim jest PiS. Badania prowadzone przez Sanecką-Tyczyńską dotyczyły lat

red. E. Maj, A. Wójcik, Lublin 2008; G. Kucharczyk, Polska myśl polityczna po roku 1939, Dębogóra, 2009; Antologia wspótczesnej polskiej myśli politycznej, red. A. Meller, G. Radomski, W. Wojdyło, Toruń 2012; Bezpieczeństwo zewnętrzne państwa w polskiej myśli politycznej po 1989 roku Wybór źródet, red. A. Lewandowski, G. Radomski, P. Tomaszewski, Toruń 2012; Partie i ugrupowania parlamentarne wobec Kościoła katolickiego w Polsce w latach 1989-2011, Szczecin 2012; Ł. Tomczak, Lewicowe partie polityczne w Polsce. Programy, organizacja, strategie, Szczecin 2012; 
2001-2007 czyli czasu, od powstania Prawa i Sprawiedliwości do zakończenia rządów z udziałem tej partii.

Praca składa się z pięciu rozdziałów, w dwóch pierwszych Sanecka-Tyczyńska poszukuje inspiracji dla myśli politycznej oraz podstaw ideowych proponowanego prze PiS projektu państwa. Trzy kolejne rozdziały to już z kolei przedmiotowe podejście do zagadnień: modelu ustroju państwa, organizacji władzy państwowej oraz bezpieczeństwa państwa.

Określając inspiracje dla myli politycznej Prawa i Sprawiedliwości autorka doszukuje się ich w nauce społecznej kościoła, w solidaryzmie, konserwatyzmie oraz myśli piłsudczykowskiej. Należy nadmienić, że związek każdej z tych inspiracji z PiS-em uzasadniony został logicznie i rzeczowo. Przedstawione zostały również i kontrowersje, jak np. kwestie „konserwatywności” myśli PiS. Jako uwagę, bardziej niż zarzut, można natomiast wskazać brak odniesienia do piłsudczykowskiej wizji stosunków międzynarodowych, czy też próby znalezienia odpowiedzi na pytanie o "chadeckość” Prawa i Sprawiedliwości, do której partia ta odwoływała się nader często.

Interesującym zabiegiem autorki było potraktowanie stosunku do historii Polskiej Rzeczypospolitej Ludowej, jako inspiracji myśli politycznej uzupełnionej o ocenę rzeczywistości III Rzeczypospolitej. Ta druga płaszczyzna wydaje się tym bardziej aktualna, że środowisko Jarosława Kaczyńskiego, w zasadzie po 1989 roku stale akcentowało problem transformacji systemu politycznego, zaś ocena III RP była cały czas aktualizowaną podstawa dla programu politycznego czy szerzej myśli politycznej. Jak sama autorka sugeruje: „Ocena rzeczywistości politycznej, gospodarczej i społecznej III Rzeczypospolitej stała się jednym z podstawowych składników programo- wych partii przed wyborami parlamentarnymi 2005 roku. Prawo i Sprawiedliwość wypracowało jedną z najbardziej krytycznych ocen III RP"2. Według autorki PiS nie było jednak partią tylko krytykującą, ale dostrzegającą również i plusy transformacji ${ }^{3}$ co $\mathrm{w}$ medialnej charakterystyce tej formacji nie zawsze znajduje odzwierciedlenie. Atrakcyjność tego zagadnienia, ale i jego znaczenie dla całego programu Prawa i Sprawiedliwości powodują powstanie pytanie o ewentualną możliwość wprowadzenia odrębnego rozdziału dotyczącego oceny III RP, jako inspiracji programowej.

Rozdział II poświęcony ideowym podstawom państwa rozbity został na cztery części dotyczące: konserwatywnego ładu moralnego, tradycji, porządku prawnego i solidarnego ładu społecznego. Te cztery warstwy według autorki, konstytuowały niejako ideowe ramy państwa w wizji PiS. Widoczna potrzeba, aby mówić o moralności w kontekście ładu państwowego, jak rekonstruuje autorka, miała swój początek w kryzysie moralnym społeczeństwa, jaki wywodził się z okresu PRL. Wówczas to w opinii polityków PiS, państwo, jako instytucja służąca dobru wspólnemu, przestało istnieć a zaczęły dominować „egoizmy grupowe”. Receptą na ten stan rzeczy miałyby być wartości chrześcijańskie oraz instytucja rodziny, pojmowana tradycyjnie, podlegająca ochronie i opiece państwa.

Wyjątkowo ciekawie prezentuje się $\mathrm{w}$ tej części pracy zagadnienie wartości chrześcijańskich podnoszonych przez PiS $\mathrm{w}$ zestawieniu $\mathrm{z}$ takimi problemami jak aborcja i kara śmierci. W obu przypadkach Sanecka-Tyczyńska umiejętnie rekonstruuje poglądy środowiska Prawa i Sprawiedli-

J. Sanecka-Tyczyńska, Państwo obywatelskie i wspólnota polityczna. Studium o myśli politycznej Prawa i Sprawiedliwości, Lublin 2011, s. 48.

3 Ibidem, s. 61. 
wość, wykazując również wewnątrzpartyjne różnice zdań.

Autorka recenzowanej książki podaje również, że jedną z głównych cech myśli politycznej PiS było szczególne znaczenie i rola ładu moralnego. Nad jego zapewnieniem czuwać miało państwo, które wytyczałoby kierunki tegoż moralnego porządku. Jednocześnie jednak, Sanecka-Tyczyńska dochodzi do wniosku, że katolicyzm był przez PiS traktowany instrumentalnie, jako narzędzie do rekonstrukcji państwa.

Inną podstawą ideową była tradycja, Jak konstatuje Sanecka-Tyczyńska: „Politycy PiS odwoływali się do postaci i wydarzeń z rożnych epok historycznych. Uogólniając, można stwierdzić, że skupiono się na tradycji świeckiej, republikańskiej, romantycznej, piłsudczykowskiej i solidarnościowej oraz chrześcijańskiej"4.

W części pracy poświęconej solidaryzmowi społecznemu autorka odnosi się również do zarzutów stawianych PiS o wprowadzenie autorytaryzmu i zestawia je, co czyni w bardzo ciekawy sposób, z sanacją. Same zarzuty uważa za bezpodstawne i sugeruje, że trafne jest określenie Jadwigi Staniszkis, iż PiS nie rozumie działania nowoczesnej demokracji ${ }^{5}$.

W końcowej części rozdziału II znajdują się cząstkowe rozważania o podziale władz proponowanym przez PiS. Pojawia się tu pewien problem dotyczący struktury pracy, otóż rozdział IV zatytułowany „Organizacja władzy państwowej” jest w całości poświęcony temu zagadnieniu.

Z kolei część trzecia pracy „Model ustroju państwowego" wydaje się treścią odbiegać od tytułu. W tej partii książki bowiem autorka rozważa czym w koncepcjach politycznych PiS-u jest suweren?, ja-

\footnotetext{
4 Ibidem, s. 92-93.

5 Ibidem, s. 127.
}

kie powinny być podwaliny legitymizacji władzy? oraz jakie funkcje powinien wypełniać system polityczny? W ramach tego rozdziału autorka $m$. in. rekonstruuje definicję narodu, jaką proponują politycy PiS. Jak zauważa w tym przypadku etniczny czynnik nie był eksponowany a ważniejsze z perspektywy narodotwórczej były wspólne wyznawane zasady i wartości moralne oraz lojalność wobec Rzeczypospolitej. Warto w tym miejscu zaznaczyć, że rozważania o narodzie mają walor wieloaspektowości i stanowią interesujący element książki.

Odnosząc się do kwestii suwerenności, Sanecka-Tyczyńska sugeruje, że PiS zaakceptowało zasadę suwerenności narodu ze wszystkimi jej konsekwencjami ustrojowymi, takimi jak np. zasada przedstawicielstwa.

Rozdział IV, którego tytuł już został wcześniej wymieniony podzielony została przedmiotowo. Każda z jego części dotyczyła poszczególnych instytucji państwowych: prezydenta, parlamentu, rządu, trybunałów i sadów, organów kontroli państwowej i ochrony państwa oraz samorządu terytorialnego. Poczynione w tej części książki rozważania w wyczerpujący sposób przedstawiają propozycje ustrojowe Prawa i Sprawiedliwości, które autorka ocenia, jako mieszczące się między „parlamentarnym a prezydenckim systemem rzadów”, jako „kompilacje różnych rozwiązań ustrojowych: modelu francuskiego i amerykańskiego". Za nowatorskie z kolei uznaje $\mathrm{m}$. in. umieszczenie prezydenta poza trójpodziałem władzy, co według niej było zbieżne z rozwiązaniami Konstytucji kwietniowej ${ }^{6}$.

Ostatnia część pracy dotyczyła, miejsca, znaczenia oraz kształtu idei bezpieczeństwa

${ }^{6}$ Ibidem, s. 173-174. 
państwa w myśli politycznej Prawa i Sprawiedliwości. Samo pojęcie bezpieczeństwa państwa zostało przez autorkę ujęte wieloaspektowo, co odzwierciedlone zostało w konstrukcji rozdziału. Czytelnikowi zostały zatem zaproponowane podrozdziały o tytułach: bezpieczeństwo polityczne, bezpieczeństwo kulturowe, bezpieczeństwo publiczne, bezpieczeństwo ekonomiczne i energetyczne oraz bezpieczeństwo militarne. Taka propozycja odzwierciedla paradygmat komplementarnego podejścia do zagadnienia bezpieczeństwa państwa, obecny we współczesnych naukach społecznych.

Interesującym obszarem, oryginalnym jak na polską myśl polityczną było bezpieczeństwo kulturowe. Jego realizacji podporządkowane miałyby być działania przeciwdziałające zagrożeniom dla tożsamości kulturowej narodu. Wyróżnienie tego obszaru z myśli PiS wydaje się jak najbardziej zasadne. Autorka jednak w zbyt dużym stopniu skupiła się na zagrożeniach związanych z Unią Europejską, a za mało poświęciła np. polityce historycznej proponowanej przez partię Jarosława Kaczyńskiego.

Innym ważnym punktem myśli politycznej PiS był również energetyczny wymiar bezpieczeństwa państwa, który autorka uznała za jeden z obszarów bezpieczeństwa ekonomicznego. Problematyczne natomiast jest umieszczenie problematyki wizji polityki zagranicznej PiS w ramach części książki poświęconej bezpieczeństwu militarnemu. Wydaje się, że tak ważkie zagadnienie jak koncepcje relacji międzynarodowych powinny posiadać wyodrębnione miejsce w książce.

Recenzowana praca stanowi wielce interesującą próbę analizy koncepcji politycznych Prawa i Sprawiedliwości i można śmiało powiedzieć, że jest jedną z ciekawszych propozycji w ramach badań nad współczesną polską myślą polityczną. Autorce udało się w sposób interesujący oraz wyczerpujący przedstawić myśl polityczną ciągle istniejącej partii. Samo podjęcie tego tematu można uznać za odważny ruch.

Za równie odważne jak i problematyczne było również zastosowanie przez autorkę do badania myśli politycznej metody systemowej. Potraktowanie koncepcji politycznych, jako określonego systemu, uzasadnianie przez autorkę we wstępie pracy, wydaje się zabiegiem wątpliwym i nie do końca oddaje ducha tego podejścia naukowego $^{7}$.

Konstrukcja książki wydaje się być przemyślaną decyzją, aczkolwiek z kilkoma wyborami autorki można polemizować. Jako jeden z zarzutów wobec książki można podać, że nie posiada ona oddzielnego rozdziału poświęconego np. kwestii modelu gospodarczego czy wspomnianych już wcześniej relacji międzynarodowych. Te treści pojawiają oczywiście w książce (o gospodarce Czytelnik, może przeczytać, np. w części nt. solidaryzmu), jednak poświęcenie tym zagadnieniom większej ilości miejsca oraz ich wyodrębnienie z pewnością mogłoby uatrakcyjnić jeszcze książkę. Tym bardziej, że sama autorka te właśnie zagadnienia poruszała już w sposób obszerny w artykułach publikowanych na łamach chociażby pism naukowych.

Jedną z zalet książki była natomiast skrupulatność autorki oraz jej starania o jasność przekazu. Dla całej książki charakterystyczne jest, że gdy pojawia się hasło bądź slogan proponowany przez PiS, SaneckaTyczyńska stara się go wyjaśnić oraz przedstawić z w zgodzie z narracją autorów, ale także i zestawiać z teoriami nauk społecz-

7 Patrz np. P. Sztompka, Analiza systemowa w naukach politycznych, [w:] Metodologiczne i teoretyczne problemy nauk politycznych, red. K. Opałek, Warszawa 1975, s. 100; 
nych. Przykładem takiego pojęcia była np. demokracja nieliberalna, która dla polityków PiS oznaczała „taki ustrój państwowy, w którym demokratycznie wybrana władza była traktowana pozytywnie - jako czynnik sprzyjający rozwojowi obywateli. Miała więc prawo do nadzwyczajnych interwencji w różne dziedziny, by chronić wspólnotę i dobro wspólne obywateli"s.

Należy pochwalić autorkę również za urozmaicenie wywodu nad myślą polityczną przez odnoszenie się do teorii socjolo-

8 J. Sanecka-Tyczyńska, op. cit., s. 120. gicznych i politologicznych oraz innych koncepcji politycznych. Zawartość książi emanuje wysokim warsztatem naukowym autorki oraz swobodą w poruszaniu się na całym polu nauk społecznych.

Reasumując należałoby uznać recenzowaną pracę za jedną z ciekawszych monografii dotyczących współczesnej polskiej myśli politycznej, która powinna być lekturą powszechną nie tylko dla politologów ale także dla dziennikarzy opisujących polityczną rzeczywistość, często nie posiadając dostatecznej wiedzy na temat politycznego myślenia opisywanych ugrupowań. 